\title{
Botany
}

\section{New record of Golovinomyces ambrosiae on Solanum azureum (Solanaceae) in Mexico.}

\begin{tabular}{|c|c|}
\hline Journal: & Botany \\
\hline Manuscript ID & cjb-2021-0106.R1 \\
\hline Manuscript Type: & Note \\
\hline $\begin{array}{r}\text { Date Submitted by the } \\
\text { Author: }\end{array}$ & 21-Aug-2021 \\
\hline Complete List of Authors: & $\begin{array}{l}\text { Félix-Gastélum, Rubén; Universidad Autónoma de Occidente } \\
\text { Leyva-Madrigal, Karla ; Universidad Autónoma de Occidente } \\
\text { Quiroz-Figueroa, Francisco ; Instituto Politécnico Nacional } \\
\text { Mora-Carlón, Bertha ; Universidad Autónoma de Occidente } \\
\text { Mora-Romero, Guadalupe; Universidad Autónoma de Occidente }\end{array}$ \\
\hline Keyword: & Powdery mildew, silverleaf nightshade, endemic host, ITS, TUB2 \\
\hline $\begin{array}{r}\text { Is the invited manuscript for } \\
\text { consideration in a Special } \\
\text { Issue? : }\end{array}$ & Not applicable (regular submission) \\
\hline
\end{tabular}

\section{SCHOLARONE \\ Manuscripts}


1 New record of Golovinomyces ambrosiae on Solanum azureum (Solanaceae) in Mexico.

2 Rubén Félix-Gastélum ${ }^{1 *}$, Karla Yeriana Leyva-Madrigal ${ }^{1 *}$, Francisco Roberto Quiroz-

3 Figueroa $^{2}$, Mora-Carlón Bertha Alicia ${ }^{1}$, Guadalupe Arlene Mora-Romero ${ }^{1}$

4 ' ${ }^{1}$ Universidad Autónoma de Occidente, Unidad Los Mochis, 81223, Los Mochis, Sinaloa, 5 México.

$6 \quad{ }^{2}$ Instituto Politécnico Nacional, Centro Interdisciplinario de Investigación para el Desarrollo 7 Integral Regional (CIIDIR)- Unidad Sinaloa, 81101 Guasave, Sinaloa, México.

$9 \quad *$ These authors contributed equally to this work.

10 Guadalupe Arlene Mora-Romero, Unidad de Investigación en Ambiente y Salud-Unidad

11 Regional Los Mochis, 81223, Los Mochis, Sinaloa, México, +52 6688161050, fax +52

12 6688161001, arlene.mora@uadeo.mx

13 Competing interests: The authors declare that there are no competing interests. 


\section{Abstract}

22 We report the powdery mildew Golovinomyces ambrosiae for the first time on silverleaf 23 nightshade (Solanum azureum), a host plant endemic to northern Sinaloa and southern 24 Sonora, Mexico. No teleomorph was observed, requiring the fungal species to be identified

25 based on morphological characteristics of the anamorph. Phylogenetic analyses of the ITS 26 region and the partial sequence of the $\beta$-tubulin gene from four specimens confirmed the 27 identity of the species. To our knowledge, this is the first report of G. ambrosiae on $S$. 28 azureum in Mexico and worldwide.

29 Keywords: Powdery mildew, silverleaf nightshade, endemic host, ITS, TUB2.

30

31

32

\section{Introduction}

Powdery mildews (PM) are members of the family Erysiphaceae in the order Erysiphales (Takamatsu 2013a) that infect angiosperms such as agricultural crops and ornamentals (Bushnell 2002) with a worldwide distribution (Ellingham and Culham 2019). Since the teleomorphs are only rarely found in tropical or subtropical regions, the characteristics of the anamorphs may be used for preliminary identifications of PM species. Additionally, substantiated identifications of these phytopathogenic fungi often requires confirmations by molecular techniques (Ellingham and Culham 2019).

The causal agents of PM are obligate parasites (Nicot et al. 2002). The mycelium is typically epiphytic, except in the genera Leveillula, Phyllactinia, Pleochaeta, and in one species of Cystotheca in which the mycelium is hemiendophytic. Furthermore, in Cystotheca, the pathogen produces superficial hyphae that penetrate the leaves through the stomata and produce mycelia inside, in contrast to species of Leveillula where mycelia are abundant 
within the leaf of the host plant (Braun et al. 2002). Although the study of PM in Sinaloa, Mexico is in its initial stages, reports of PM diseases include Podosphaera xanthii (Castagne) U. Braun and Shishkoff in cucurbits and husk tomatoes (Physalis philadelphica Lam.); Erysiphe quercicola S. Takam. and U. Braun (= Pseudoidium anacardii (F. Noack) U. Braun and R. T. A. Cook) on mango; Erysiphe diffusa (Cooke and Peck) U. Braun and S. Takam. on common bean; and Podosphaera pannosa (Wallr.) de Bary on roses (Félix-Gastélum et al. 2016). In addition, Golovinomyces spadiceus (Berk. and M.A. Curtis) U. Braun has been reported on wild sunflower (Félix-Gastélum et al. 2019). Furthermore, Phyllactinia (Ovulariopsis cf. insolita) has been reported on Funastrum clausum (Jacq.) Schltr. and F. cynanchoides (Decne.) Schltr. (Bojórquez-Ramos et al. 2014). Recently, Phyllactinia chubutiana, was reported on Vallesia glabra (Cav.) Link (Félix-Gastélum et al. 2021). In the winter of 2021, signs of PM were observed on silverleaf nightshade (Solanum azureum Fernald) for the first time in Mexico. This solanaceous desert shrub is endemic to northern Sinaloa and southern Sonora, Mexico (Fig. 1A) (Knapp et al. 2017; https://herbanwmex.net/portal/taxa/index.php?taxon=28402\&clid=3810). Although this shrub grows along irrigation canals, railroads, and abandoned lots in urban areas, it has not been reported to compete with agricultural crops in the region.

The initial signs of PM disease on silverleaf nightshade consist of small, powdery white lesions $0.5-2.0 \mathrm{~mm}$ in diameter (Fig. 1B). As the disease progresses, the lesions cover both the upper (Fig. 1C) and lower leaf surfaces. We observed that structures of the anamorph of the pathogen were copious on infected leaves, while the teleomorph was not observed during the sampling period. To our knowledge, this is the first report of this powdery mildew on $S$. azureum in Mexico.

\section{Materials and methods}


68 Four samples each consisting of 20 symptomatic leaves were collected in the municipality of Ahome, Sinaloa from January 8 through March 10, 2021 (Table 1). Symptomatic plants were

identified at the species level, and a representative sample was deposited at the herbarium of the Universidad Autónoma de Occidente in Los Mochis, Sinaloa, Mexico.

Measurements of somatic and asexual structures were performed in fresh specimens by touching the lesions with a transparent sticky tape and mounting it in a drop of $0.4 \%$ cotton blue in lactic acid on a microscope slide. Mountings were observed under a compound microscope (Labomed; Labo America, Inc., USA). Forty fungal structures of the anamorph from four sampling sites were measured $(n=160)$. The presence or absence of fibrosin bodies in fresh conidia was determined according to previously described procedures (Kable et al. 1963). To examine conidial germination, conidia were transferred from naturally infected leaves to sterilized microscope slides using a smooth-bristled brush. Subsequently, conidia $(\mathrm{n}=80)$ were incubated for $24-48 \mathrm{~h}$ at $100 \%$ relative humidity and $23 \pm 2{ }^{\circ} \mathrm{C}$. The length of the germ tube and its width at the midpoint were measured. Light micrographs of conidiophores and conidia were obtained with a microscope (Leica DM6000 CS, LAS AF version 2.5.0.6735), while the images of hyphal appressoria and germinated conidia were acquired using a compound microscope (Axio Imager M2; Carl Zeiss, Göttingen, Germany). DNA extraction, $P C R$, and sequencing

For molecular identification, a small amount $(\sim 50 \mathrm{mg})$ of somatic and reproductive structures of four specimens $(\mathrm{Sa}-1-\mathrm{Sa}-4)$ were transferred from infected leaves to 1.5-mL Eppendorf tubes using a fine paintbrush. Genomic DNA extraction was performed using $500 \mu \mathrm{L}$ of DNAzol ${ }^{\circledR}$ (Thermo Fisher Scientific; Cincinnati, OH, USA) according to the manufacturer's instructions. The extracted DNA was resuspended in $30 \mu \mathrm{L}$ of nuclease-free water, and then 
91 one $\mu \mathrm{L}$ of a ten-fold dilution was used as a template for the first round of nested PCR with 92 the primer set ITS1/ITS4 (White et al. 1990). One $\mu \mathrm{L}$ of this first reaction was used for amplification with primers ITS4 and the Erysiphaceae-specific primer PM5 (Takamatsu and

94 Kano 2001). Additionally, a PCR reaction was conducted using the TubF1/TubR1 primer set to amplify $\sim 450 \mathrm{bp}$ of the partial $\beta$-tubulin (TUB2) gene sequence (Qiu et al. 2020).

The PCR mixes contained $2.5 \mu \mathrm{L}$ of buffer, $0.75 \mu \mathrm{L}$ of $50 \mu \mathrm{mol} / \mathrm{L} \mathrm{MgCl} 2,1.0 \mu \mathrm{L}$ of each primer $(10 \mu \mathrm{mol} / \mathrm{L}), 1 \mu \mathrm{L}$ of $10 \mathrm{mmol} / \mathrm{L}$ dNTP mix, $0.1 \mu \mathrm{L}(1 \mathrm{U})$ of Taq DNA polymerase (Invitrogen, USA), $1.0 \mu \mathrm{L}$ of template DNA, and nuclease-free water for a final volume of

$9925 \mu \mathrm{L}$. PCR amplifications were performed in an Apollo ATC-201 PCR cycler (Nyx 100 Technik; San Diego, CA, USA), using the following program conditions: an initial 101 denaturing step at $94^{\circ} \mathrm{C}$ for $5 \mathrm{~min} ; 35$ cycles consisting of $30 \mathrm{~s}$ at $94^{\circ} \mathrm{C}$ followed by $30 \mathrm{~s}$ at $10258^{\circ} \mathrm{C}$ (ITS) or $52^{\circ} \mathrm{C}$ (TUB2) for annealing and $30 \mathrm{~s}$ at $72^{\circ} \mathrm{C}$ for extension; and a final 103 extension cycle of $5 \mathrm{~min}$ at $72^{\circ} \mathrm{C}$. The $\mathrm{PCR}$ products were sent for purification and 104 sequencing to Macrogen Inc (Seoul, Korea).

105 Phylogenetic analysis

106 Sequences were edited in BioEdit v 7.0.5.3 (Hall 1999) and aligned with reference sequences 107 of the G. ambrosiae complex and related species (Qiu et al. 2020), using the MUSCLE 108 algorithm (Edgar 2004) implemented in MEGA X (Kumar et al. 2018). The best-fitting 109 partitioning scheme was selected using unlinked branch lengths, greedy algorithm, and the 110 Akaike Information Criterion (AIC) in PartitionFinder v 1.1.1 (Lanfear et al. 2012). Finally, 111 the phylogenetic analysis was conducted with Maximum Likelihood (ML) in RAXML v 1127.2 .8 (Stamatakis 2006), using the GTRGAMMAI model for each partition identified by 113 Partition Finder and 1000 rapid bootstraps.

\section{Results}




\section{Morphological characteristics}

Since the teleomorph of the fungus was not found during the sampling period, all morphological studies were performed on the anamorph. We observed ectophyticamphigynous mycelium of PM on infected plants. Hyphal width was (3.7-) $5.0-7.5(-10.0)$ $\mu \mathrm{m}$ (5.6 $\mu \mathrm{m}$ on average), with solitary nipple-shaped hyphal appressoria (Fig. 1D). Conidiophores (Euoidium-type) emerged from the superficial mycelium, measured (12.5-) $87.5-100.0(-162.5) \mu \mathrm{m}$ in length $\times(5.0-) 10.0-12.5(-15.0) \mu \mathrm{m}$ in width $(107.1 \times 10.5$ $\mu \mathrm{m}$ on average) with straight foot cell of (25.0-) $25.0-37.5(-90.0) \mu \mathrm{m}$ in length $\times(3.2-)$ 5.0-7.5 $(-15.0) \mu \mathrm{m}$ in width $(38.5 \times 6.3 \mu \mathrm{m}$ on average $)$. Conidia were ellipsoid-ovoid and cylindrical, without any fibrosin bodies (Fig. 1F), (25.0-) 32.5-37.5 (-45.0) $\mu \mathrm{m}$ in length $\times$ (10.0-) 15.0-17.5 $(-22.5) \mu \mathrm{m}$ in width $(32.9 \times 16.0 \mu \mathrm{m}$ on average $)$, with an average length/ratio of 2.0. Germ tubes were simple, emerging on shoulders, rarely at the end of the conidia (Fig. 1G), and measured (15.0-) 25.0-27.5 (-42.5) $\mu \mathrm{m}$ in length $\times(2.5-)$ 2.5-2.7 (5.0) $\mu \mathrm{m}$ in width $(26.4 \times 2.9 \mu \mathrm{m}$ on average $)$.

Phylogenetic analysis

Sequences of the ITS region and the TUB2 gene were compared with sequences in the NCBI database using the BLAST and MegaBLAST algorithms. The comparison of ITS sequences revealed a $99.78 \%$ identity with G. ambrosiae, G. spadiceus and G. latisporus (GenBank accession numbers MT355557, KX821733 and MK452603, respectively). A 99.17\% - 100\% identity with G. ambrosiae and G. latisporus (GenBank accession numbers MK389490 and MK452495, respectively) was recorded using the TUB2 sequences.

The final combined alignment (ITS + TUB2) consisted of $648 \mathrm{bp}$. PartitionFinder suggested the same partition for the ITS region and all codon positions (first, second and third) of the 
138 TUB2 gene $(\operatorname{lnL}=-1325.61)$. The inferred phylogram from the combined alignment showed 139 the grouping of four specimens associated with silverleaf nightshade (S. azureum) to $G$. 140 ambrosiae, in a well-supported clade (99\% bootstrap; Figure 2). Specimen sequences were 141 deposited in GenBank with the following accession numbers: MW934451-MW934453 for 142 ITS, and MW929327-MW929330 for TUB2 (Table 1).

\section{Discussion}

144 Our results show that the morphological features of the anamorph of the PM associated with 145 Solanum azureum coincide with those reported as Golovinomyces spadiceus from Sinaloa,

147 latisporus on Helianthus spp. [previously referred to as G. ambrosiae (Braun and Cook 148 2012)], based on morphological characteristic. Phylogenetic analyses of the ITS region and 149 the TUB2 gene revealed a correspondence with G. ambrosiae, including G. spadiceus as 150 synonym, as recently reassessed and re-circumscribed on the basis of multi-locus 151 phylogenetic analysis, in which G. ambrosiae and G. spadiceus proved to be conspecific (Qiu 152 et al. 2020). Individual and combined gene analysis strongly grouped both species names in 153 the same clade, which was renamed as G. ambrosiae (containing G. spadiceus). Widely 154 distributed throughout Australia, Asia, Europe and North America, this plurivorous species 155 occurs on Ambrosia spp., as well as numerous species of various genera belonging to the 156 Asteraceae, Fabaceae, Solanaceae and Verbenaceae families (Qiu et al. 2020). The incidence 157 of G. ambrosiae on S. azureum, a plant endemic to northern Sinaloa and southern Sonora, 158 Mexico (Knapp $\quad$ et $\quad$ al. 2017; 159 https://herbanwmex.net/portal/taxa/index.php?taxon=28402\&clid=3810), is relevant since 160 this fungus is referred to as plurivorous, even though it has not yet been reported associated 161 with any member of the Solanaceae in Mexico. 
162 Several Golovinomyces spp. have been reported on members of Solanaceae (Cunnington et 163 al. 2005, Braun and Cook 2012). Braun et al. (2019) listed members of Solanaceae among 164 the hosts of G. spadiceus (now G. ambrosiae), which goes back to Takamatsu et al. (2013b), 165 who included a sequence retrieved from a North American powdery mildew sample on 166 Solanum carolinianum in Lineage III. To our knowledge this is the first report of $G$. 167 ambrosiae on a member of Solanaceae in Mexico and the first record of this species on 168 Solanum azureum. Future research projects should be directed at determining the incidence 169 of G. ambrosiae on other solanaceous plants in Sinaloa, including agricultural crops 170 important to this region.

171 Acknowledgments

172 The authors thank Dr. Jerzy Rzedowski Rotter (Emeritus professor at the Ecology Institute, 173 Mexico) for identification of the plant species Solanum azureum included in the present 174 study. The authors also express their gratitude to Dr. Uwe Braun (Full Professor at the Martin 175 Luther University, Halle-Wittenberg Institute of Biology, Germany) for his comments which 176 were very helpful in improving the manuscript. Financial support for this project was 177 provided by the Research and Graduate Division of the Universidad Autónoma de Occidente.

\section{References}

180 Braun, U., and Cook, R. 2012. Taxonomic manual of the Erysiphales (powdery mildews). CBS Biodiversity Series. 11. Utrecht, the Netherlands.

182 Braun, U., Cook, R.T.A., Inman, A.J., and Shin, H.D. 2002. The taxonomy of the powdery mildew fungi. In The powdery mildews: a comprehensive treatise. Edited by R.R. 
186

187

188

189

190

191

192

193

194

195

196

197

198

199

200

201

202

203

204

205

206

207

208

Braun, U., Shin H.-D., Takamatsu, S., Meeboon, J., Kiss. L., Lebeda. A., Kitner. M., and Götz. M. 2019. Phylogeny and taxonomy of Golovinomyces orontii revisited. Mycol. Prog. 18: 335-357.

Bushnell, W.R. 2002. The role of powdery mildew research in understanding host parasite interaction: Past, present, and future. In The powdery mildews: a comprehensive treatise. Edited by R.R. Bélanger, W.R. Bushnell, A.J. Dik, and T.L.W. Carver. American Phytopathological Society Press, St. Paul, Minn. pp. 1-12

Cunnington, J. H., Lawrie, A.C., and Pascoe, I. G. 2005. Molecular identification of Golovinomyces (Ascomycota: Erysiphales) anamorphs on the Solanaceae in Australia. Australas. Plant Pathol. 34: 51-55. doi:10.1071/AP04082.

Edgar, R.C. 2004. MUSCLE: multiple sequence alignment with high accuracy and high throughput. Nucleic Acids Res. 32(5): 1792-1797. doi:10.1093/nar/gkh340.

Ellingham, O., David, J., and Culham, A. 2019. Enhancing identification accuracy for powdery mildews using previously underexploited DNA loci. Mycologia, 111(5):798812. doi: $10.1080 / 00275514.2019 .1643644$.

Félix-Gastélum, R., Maldonado-Mendoza, I.E., Beltrán-Peña, H., Apodaca-Sánchez, M.A., Espinosa-Matías, S., Martínez-Valenzuela, M.C., et al. 2016. Powdery mildews in agricultural crops of Sinaloa: Current status on their identification and future research lines. Rev. Mex. Fitopatol. 35: 106-129. doi:10.18781/R.MEX.FIT.1607-4.

Félix-Gastélum, R., Olivas-Peraza, D.D., Quiroz-Figueroa, F.R., Leyva-Madrigal, K.Y., Peñuelas-Rubio, O., Espinosa-Matías, S., and Maldonado-Mendoza, I.E. 2019. Powdery mildew caused by Golovinomyces spadiceus on wild sunflower in Sinaloa, Mexico. Can. J. Plant Pathol. 41(2): 301-309. doi:10.1080/ 07060661.2019.1577916. 
209

210

211

212

213

214

215

216

217

218

219

220

221

222

223

224

225

226

227

228

229

230

231

Félix-Gastélum, R., Leyva-Madrigal, K.Y., Quiroz-Figueroa, F.R., Rodriguez-Mora, N., Maldonado-Mendoza, I.E., Espinosa-Matías, S., and Mora-Romero, G.M. 2021. First report of Phyllactinia chubutiana, nom. cons., on Vallesia glabra (Apocynaceae) in Mexico. Botany, 99 (5): 281-287.doi.org/10.1139/cjb-2020-0211.

Hall, T.A. 1999. BioEdit: a user-friendly biological sequence alignment editor and analysis program for Windows 95/ 98/NT. Nucleic Acids Symp. Ser. 41: 95-98. doi:10.14601/ Phytopathol_Mediterr-14998u1.29.

Kable, P.F., Ballantyne, B., and Barbara, J. 1963. Observations on the cucurbit powdery mildew in the Ithaca district. Plant Dis. Rep. 47:842.

Knapp, S., Sagona, E., Carbonell, A. K.Z., and Chiarini, F. 2017. A revision of the Solanum elaeagnifolium clade (Elaeagnifolium clade; subgenus Leptostemonum, Solanaceae). PhytoKeys, 84: 1-104. doi:10.3897/phytokeys.84.12695.

Kumar, S., Stecher, G., Li, M., Knyaz, C., and Tamura, K. 2018. MEGA X: Molecular Evolutionary Genetics Analysis across computing platforms. Mol. Biol. Evol. 35(6): 1547-1549. doi:10.1093/molbev/msy096.

Lanfear, R., Calcott, B., Ho, S.Y.W., and Guindon, S. 2012. PartitionFinder: combined selection of partitioning schemes and substitution models for phylogenetic analyses. Mol. Biol. Evol. 29:1695-1701. doi:10.1093/molbev/mss020.

Nicot, P.C., Bardin, M., and Dik, A.J. 2002. Basic methods for epidemiological studies of powdery mildews: Culture and preservation of isolates, production and delivery of inoculum, and disease assessment. In The powdery mildews: a comprehensive treatise. Edited by R.R. Bélanger, W.R. Bushnell, A.J. Dik, and T.L.W. Carver. American Phytopathological Society Press., St. Paul, Minn. pp. 83-99. 
232 233

234 235 236 237 238 239 240

241 242 243 244 245 246

Qiu, P.L., Liu, S.Y., Bradshaw, M., Rooney-Latham, S., Takamatsu, S., Bulgakov, T.S., ShuRong, T., Feng, J., Jin, D.N., Aroge, T., Li, Y., Wang, L.L., and Braun, U. 2020. Multilocus phylogeny and taxonomy of an unresolved, heterogeneous species complex within the genus Golovinomyces (Ascomycota, Erysiphales), including G. ambrosiae, G. circumfusus and G. spadiceus. BMC Microbiol. 20: 51. doi:10.1186/s12866-02001731-9.

Stamatakis, A. 2006. RAxML-VI-HPC: maximum likelihood-based phylogenetic analyses with thousands of taxa and mixed models. Bioinformatics, 22(21): 26882690. doi:10.1093/bioinformatics/bt1446.

Takamatsu, S. 2013a. Origin and evolution of the powdery mildews (Ascomycota, Erysiphales). Mycoscience, 54(1): 75-86. doi:10.1016/j.myc.2012.08.004.

Takamatsu, S., and Kano, Y. 2001. Primers useful for nucleotide sequencing of rDNA of the powdery mildew fungi. Mycoscience, 42(1): 135-139. doi.org/10.1007/BF02463987.

Takamatsu, S., Matsuda, S., and Grigaliunaite, B. 2013b. Comprehensive phylogenetic analysis of the genus Golovinomyces (Ascomycota: Erysiphales) reveals close evolutionary relationships with its host plants. Mycologia, 105: 1135-1152.

White TJ, Bruns TD, Lee SB, Taylor JW, 1990. Analysis of phylogenetic relationships by amplification and direct sequencing of ribosomal DNA genes. In PCR protocols: A Guide to Methods and Applications. Edited by M.A. Innis, D. H. Gelfand, J.J Sninsky, and T.J. Academic Press, San Diego. pp. 315-322. 
253 Table 1. Data for Golovinomyces ambrosiae associated with Solanum azureum.

\begin{tabular}{|c|c|c|c|c|c|}
\hline \multirow{2}{*}{ Sample } & \multirow{2}{*}{ Locality } & \multirow{2}{*}{$\begin{array}{c}\text { Collection } \\
\text { date (in } \\
2021)\end{array}$} & \multirow{2}{*}{ Coordinates } & \multicolumn{2}{|c|}{ GenBank Accession no. } \\
\hline & & & & ITS & TUB2 \\
\hline \multirow[t]{2}{*}{$S a-1$} & Cahuinahua & January 8 & $26^{\circ} 31^{\prime} 15^{\prime \prime} \mathrm{N}$ & - & MW929327 \\
\hline & & & $109^{\circ} 12^{\prime} 44^{\prime \prime} \mathrm{O}$ & & \\
\hline \multirow[t]{2}{*}{$S a-2$} & Cahuinahua & January 8 & $26^{\circ} 02^{\prime} 44^{\prime \prime} \mathrm{N}$ & MW934451 & MW929328 \\
\hline & & & $109^{\circ} 13^{\prime} 08^{\prime \prime} \mathrm{O}$ & & \\
\hline$S a-3$ & Canal Tabelojeca & March 10 & $26^{\circ} 01^{\prime} 55^{\prime \prime} \mathrm{N}$ & MW934452 & MW929329 \\
\hline$S a-4$ & Canal Tabelojeca & March 10 & $26^{\circ} 01^{\prime} 21^{\prime \prime} \mathrm{N}$ & MW934453 & MW929330 \\
\hline & & & $109^{\circ} 13^{\prime} 44^{\prime \prime} \mathrm{O}$ & & \\
\hline
\end{tabular}

254

255

256

257

258

259 


\section{Figure captions}

261 Figure 1. Signs of powdery mildew Golovinomyces ambrosiae specimen $\mathrm{Sa}-4$ on leaves of 262 Solanum azureum, and morphological characteristics of the fungus. A: Flowers and healthy 263 leaves of the host. B: Initial signs consisting of small, whitish circular lesions on the adaxial 264 surface of the leaf. C: Leaf covered with white powdery mildew. D: Light micrograph 265 depicting single nipple-shaped appressoria on the hyphae (black arrow). E: Conidiophore 266 with attached conidium. F: Conidium with Euoidium-type germination (black arrow). G: 267 Ovoid- to cylindrical-shaped conidia. Scale bars: D, F and $\mathrm{G}=20 \mu \mathrm{m}, \mathrm{E}=15 \mu \mathrm{m}$.

268 Figure 2. Maximum likelihood tree based on the combined ITS + TUB2 sequence datasets 269 from the Golovinomyces ambrosiae complex, G. magnicellulatus and G. circumfusus. 270 Neoerysiphe galeopsidis was used as anoutgroup. Sequences of the specimens infecting 271 Solanum azureum are shown in bold. Numbers above the branches indicate bootstrap nodal 272 support. The scale bar indicates the number of nucleotide substitutions per site. 


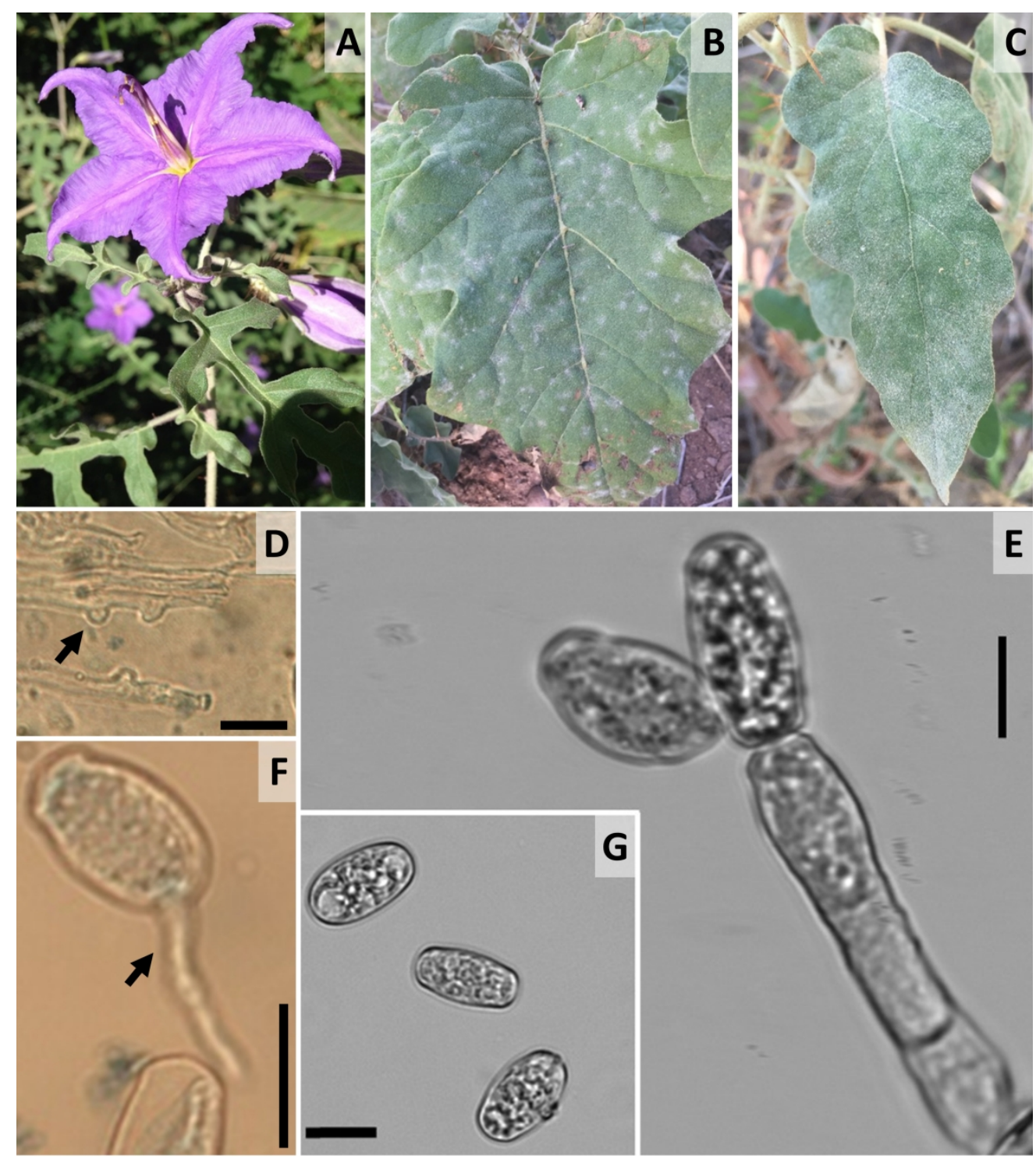

$235 \times 265 \mathrm{~mm}(300 \times 300$ DPI $)$ 


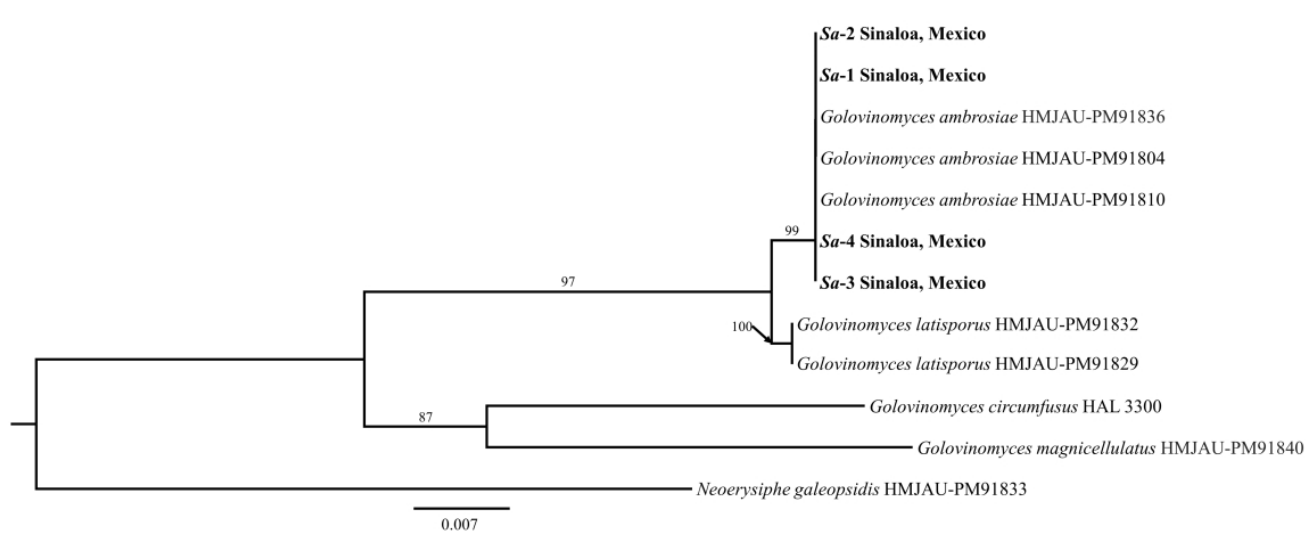

$395 \times 155 \mathrm{~mm}(300 \times 300 \mathrm{DPI})$ 